\title{
Adult Education in the Czech Republic - Who Participates and Why*
}

\author{
MILADA RABUŠICOVÁ, LADISLAV RABUŠIC** \\ Faculty of Arts and Faculty of Social Studies, Masaryk University, Brno
}

\begin{abstract}
Adult education as a part of lifelong learning is nowadays the topic emphasised in all documents concerning educational policy, employment policy, and human resources development in the Czech Republic. Older empirical data indicate, however, that the participation of the Czech adult population in programmes of adult learning is not very common. The aim of this article, which is based on a special representative survey, 'Adult Learning 2005', is to confront how far Czech reality is from the ideal concepts of 'lifelong learning' and a 'learning society'. The authors pursue three questions: 1) To what extent is it true that education in the Czech Republic is a lifelong affair? 2) Does education of this kind occur on both a formal and non-formal level? 3) Do the Czechs engage in lifelong education, regardless of age, attained level of education, gender, and occupational status? Empirical data reveal that, despite the fact that Czech educational authorities give formal support to adult education, reality 'in the field' is somewhat different. Education in the Czech Republic is still not lifelong; if it exists it occurs mainly within the framework of non-formal education, and only higher educated people and those with some experience in adult education participate in it.
\end{abstract}

Keywords: knowledge society, adult education, lifelong learning, formal and non-formal education

Sociologický časopis/Czech Sociological Review, 2006, Vol. 42, No. 6: 1195-1218

\section{Introduction}

Many analysts have conceptualised modern societies as 'knowledge societies', in which education has become the crucial element for the advancement of both individuals and societies themselves. Given that societies are also dynamic, it is evident that education must also be made more dynamic. Gone are the times when an edu-

\footnotetext{
* Research for this paper was supported by a research grant of the Ministry of Labour and Social Affairs, project no. 1J 017/04-DP2 entitled 'Adult Education in Various Stages of the Life Cycle: Priorities, Opportunities, and Possibilities of Development'. The authors thank the anonymous reviewers for their suggestions.

** Direct all correspondence to: Milada Rabušicová, Faculty of Arts, Masaryk University, Arna Nováka 1, 60200 Brno, Czech Republic, milada@phil.muni.cz; Ladislav Rabušic, Faculty of Social Studies, Masaryk University, Joštova 10, 60200 Brno, Czech Republic, rabu@fss.muni.cz
}

(C) Sociologický ústav AV ČR, Praha 2006 
cation level, once attained, was sufficient for the rest of one's life. Instead, there is a need for more or less permanent interaction between the worlds of learning, work, and living within our life trajectories. It is no surprise that a Canadian study on adult education [Statistics Canada 2001: 5] chose as its motto a statement by Marshall McLuhan, that the future of work would consist of 'learning a living'. Adult education, continuing education, or lifelong learning (as Courtney [1989] has shown, these different concepts mean more or less the same thing ${ }^{1}$ ) are therefore bound to become a salient feature of modern life in the 21st century.

In this article, which is intended to be descriptive and exploratory in nature, we present empirical results that show who participates in adult education in the Czech Republic, to what extent, and with what motivations. The data stem from a special social survey carried out among Czech adults, and they reveal that, despite the fact that Czech educational authorities give formal support to adult education, reality 'in the field' is somewhat different.

\section{Background context}

The agenda of the European Union ranks education and training among its highest political priorities.

Acquiring and continuously updating and upgrading a high level of knowledge, skills and competencies is considered a prerequisite for the personal development of all citizens and for participation in all aspects of society from active citizenship through to labour market integration. [Eurostat 2005: 1]

As Hiemstra [2002] has shown, there are three main forces that generate an interest in and the need for lifelong learning: the rapidity of social change, the continuous march by many adults towards occupational obsolescence, and a change in value systems. People realise that a full life is possible primarily by maximising individual potential.

Therefore, adult education is of utmost importance, from both a micro- and macro-perspective. At the individual (micro) level, people who do not update their skills and knowledge may be at greater risk of unemployment and thus also of poverty and social exclusion. These potentially negative effects are contradictory to the EU's vision: the Lisbon Strategy demands, among other things, active citizenship and inclusion. At the macro-level, permanent improvement in the quality of human resources is regarded as a key factor in the success of national economies in competitive global markets.

${ }^{1}$ On the other hand, Boshier [2001] maintains that there is a regrettable tendency for scholars and political analysts to use lifelong learning and lifelong education as synonyms. He sees them as different because they serve different interests. 
In the Czech Republic there is a shared belief that the Czech population has traditionally always been well educated and equipped with relevant skills. This belief has come close to being a national self-stereotype and a source of national pride. However, comparative data at the level of educational attainment reveal that this view is not entirely accurate; statistical data on educational attainment speak quite clearly: in 2003, $12 \%$ of people aged 25-64 in the Czech Republic had tertiary education (type 5B+5A in ISCED terminology), one of the lowest figures among all OECD countries, while in France, the Netherlands, Belgium or Finland, for example, the figure is more than double. On the other hand, it is true that, as far as upper secondary education is concerned, the Czech Republic is above the average: among OECD countries an average of $41 \%$ of the population aged 25-64 years attained upper secondary education (ISCED 3A + 3C Short + Long 3B), compared with $75 \%$ in the Czech Republic ${ }^{2}$ [Education 2000, Table A1.1a].

The percentage of GDP allocated to education in the Czech Republic is also smaller compared to other OECD countries (4.5\% of GDP in the CR in 2001, compared to $5-7 \%$ in other advanced countries). Moreover, owing to the long-term decline in fertility, which has now been in under way for over twenty years, the size of the young cohorts entering the Czech labour market are smaller and smaller. ${ }^{3} \mathrm{~A}$ fact observed by analysts in Canada also applies to the Czech Republic: "[the] economy cannot rely as much as in previous decades on initial education to address the skill needs of the short and the medium terms. In this context, a greater share of the skills adjustment of the Canadian work force will have to be achieved through training those adults who are already in the workplace". [Statistics Canada 2001: 6]

Czech educational documents put strong verbal emphasis on the role of lifelong learning and adult education. The two basic programme documents on how to improve the Czech education system [Národni program... 2001], and the Long-term Plan for Education and the Education System in the Czech Republic [Dlouhodoby záměr... 2002]) both assert: "the concept of lifelong learning necessitates development in further education (adult education). Not only does it present an alternative way to obtaining education and qualification, but it is one of the main tools of employment policies and the company development strategy." Nevertheless, the Czech Republic has no special educational act devoted to adult education, unlike many other advanced countries. Political support for adult learning is of course only one

\footnotetext{
2 With regard to this figure it is important to know that according to ISCED 97, upper secondary education in the Czech Republic includes vocational training schools, which used to have a very strong orientation towards practical skills and had little in common with general, 'academic' secondary education. About $60 \%$ of the population used to attend this form of education, while the remaining $40 \%$ studied at grammar schools and secondary technical schools.

${ }^{3}$ However, data on demographic development suggest at least one positive consequence, specifically, the opportunity to re-locate resources (both financial and human) to higher levels of the education system and the continuing education of adults. A drop in the number of students by $20 \%$ is expected to occur at the level of primary education by 2010 ; a drop of $15 \%$ is expected at the level of secondary education.
} 
side of the coin. The other side is the readiness and willingness of the adult population to participate in adult-learning programmes. If these factors are in poor evidence, then the participation rate will be low, too. If this proves to be the case, a variety of incentives will have to be developed to motivate the adult population to participate in further education.

This problem has already been identified in Czech documents on educational development. They draw attention to the insufficient motivation of the demand for further education (among individuals as well as employers), especially among those social strata and groups in which an increased employment rate is desired most. It is increasingly evident that the path to take is the one based on financial incentives and efficient information support [adopted from Dlouhodobý záměr... 2002]. Another problem that has been identified is a lack of initiative and involvement on the part of schools and educational institutions in particular, which ought to be creating an attractive offer of continuing-education products [adopted from Ibid.].

Lifelong learning has some basic features, which will here be mentioned briefly. The first is that education is no longer limited to a certain stage of life - the school-age period - and instead spans an entire lifetime. Consequently, the sector of adult education should expand, as it is designed for those who have finished their formal education. Its relation to initial education, i.e. the traditional schooling system, has yet to be determined, and traditional schools themselves must yet undergo a transformation. Rather than passing on a certain volume of knowledge and skills, the school system's primary role will be to instil the skills necessary for self-study and to provide the motivation, based on an individual's needs, to aspire to the highest level of knowledge and skills possible and for individuals to be able to assume responsibility for their own educational careers.

The second feature of lifelong learning is that it involves not only formal education provided by educational institutions, but all forms and types of learning, regardless of the institution or the environment, be it at the workplace, in the home, or in a municipal context. All learning opportunities as a whole provide scope for multiple and diverse switches between education and employment and for the acquisition of the same qualifications and competencies via different pathways at any time during one's life.

The third feature is that of equal opportunity, guaranteed to everyone regardless of age, motivation, talent, or social status. At this point there is therefore a fundamental shift in the focus of the education system towards accommodating the heterogeneous needs, interests, and talents of various individuals to the maximum possible degree and with the maximum possible differentiation and individuation, and a shift in focus towards enabling the maximum development of each individual and the maximum use of her/his potential. A precondition for fully satisfying the needs of a society in which every members has an opportunity to choose his/her own path in education and to change it during his/her life is that there exist educational opportunities that are available to everyone and correspond to their abilities, requirements, and needs. Access to education must therefore be provided not just in legal terms but al- 
so in practice - in terms of a sufficient number of student positions, the diversity of the educational offer, and equal access to education. The requirement of equal opportunities implies, however, much more than just overcoming material barriers (e.g. with the help of a system of grants and scholarships), i.e. overcoming unequal economic status. Handicaps stemming from differences in socio-cultural or health status must also be overcome, and adequate compensatory mechanisms must be applied in order to prevent the education system from reproducing already existing inequalities.

These three features describe the three main concepts contained in the famous Faure report [1972] published by UNESCO: the vertical integration, the horizontal integration, and the democratisation of education systems. If properly applied, they should lead to the creation of what the report called the 'learning society'.

These three dimensions also form the basic focus of this article. Translated into the language of research questions, we shall pursue the following: 1) To what extent is it true that education in the Czech Republic is a lifelong matter? 2) Does education of this kind occur on both a formal and non-formal level? ${ }^{4} 3$ ) Do all Czechs engage in lifelong education, regardless of age, attained level of education, gender, and occupational status?

\section{Methodology}

The results presented in this paper are based on a representative national survey that focused on the factors that play a role in the further education of Czech adults. To the best of our knowledge this survey was one of the first comprehensive inquiries into this issue, which alone is indicative of the limited amount of attention devoted to this phenomenon. The only survey of adult education to date was conducted in 1997 as part of an IALS (International Adult Literacy Survey) study, and partially also in connection with the 'Ad Hoc Module on Lifelong Learning' carried out by the Czech Statistical Office under the auspices of Eurostat in 2003. This article is therefore largely descriptive and exploratory, its aim being to present the basic features of Czech adult education.

The data were obtained in a representative national survey performed on a sample of the adult population aged 20-65 in the Czech Republic. The research was carried out in the spring of 2005 by the prestigious research agency SC\&C and its interviewers. The sample was selected using a random statistical selection method (a random walk with Kisch tables). The response rate was $49 \%$, and the final number of respondents was 1413.

In our survey, which was called 'Adult Education in the Czech Republic', we were interested in discovering the various aspects of different forms of adult education. In conformity with the UNESCO definition (1976), we define adult education as:

\footnotetext{
${ }^{4}$ Although informal education was one of the topics of our survey and data on it are available, owing to the limited scope of this article this topic is not addressed here.
} 
the entire body of organized educational processes, whatever the content, level, and method, whether formal or otherwise, or whether they prolong or replace initial education in schools, colleges and universities as well as in apprenticeship, whereby person regarded as adult by the society to which they belong develop their abilities, enrich their knowledge, improve their technical or professional qualifications or turn them in a new direction and bring about changes in their attitudes or behavior in the two fold perspective of full personal development and participation in balanced and independent social, economic and cultural development. [quoted from Titmus 1996: 9]

The classification of forms of adult education we used agrees with, for example, 'A Memorandum of Lifelong Learning' [European Commission 2000], and is based on three main categories of purposeful learning activity: Formal education takes place in education and training institutions and leads to recognised diplomas and qualifications. It corresponds to education and training in the regular system of schools, universities, and colleges. Non-formal education takes place alongside the mainstream systems of formal education and training and does not typically end in the awarding of any formal certificates. Non-formal learning may be provided in the workplace and through the activities run by civil society organisations and groups (such as youth organisations, trade unions and political parties). It can also be provided through organisations or services that have been set up to complement formal systems (such as art, music, and sports classes or private tutoring to prepare for examinations). In sum, non-formal education and training includes all types of taught learning activities that are not a part of formal education programmes. Informal learning is a natural accompaniment to everyday life. It corresponds to independent learning that is not a part of formal or non-formal education and training and is instead based on different methods, such as books, computers, learning centres, or educational broadcasting. Unlike formal and non-formal education, informal learning is not necessarily intentional learning, and so may well not be recognised even by the individuals themselves as contributing to their knowledge and skills.

In our conceptualisation of the problem, we were inspired by Cross's influential 'chain of response model', which assumes that participation in any learning activity is not a single act but the result of a chain of responses, each of which is based on an evaluation of the position of the individual in his/her environment [Cross 1981: 125]. Cross's chain contains seven stages or links: self-evaluation, attitudes about education, the importance of goals and the expectation that they will be met, life transitions, opportunities and barriers, information on educational opportunities, and the decision to participate; the model assumes that each stage influences other stages.

However, the conceptual model on which we ultimately based our research (see Figure 1) derives from the socio-psychological theory of reasoned action [Ajzen and Fishbein 1980] and from rational choice theory, based on Becker's assumption that when making decisions about their behaviour people weigh the costs and benefits of that behaviour [Becker 1993]. We believe that people make rational decisions based on the information available to them. The information they have depends on 
告

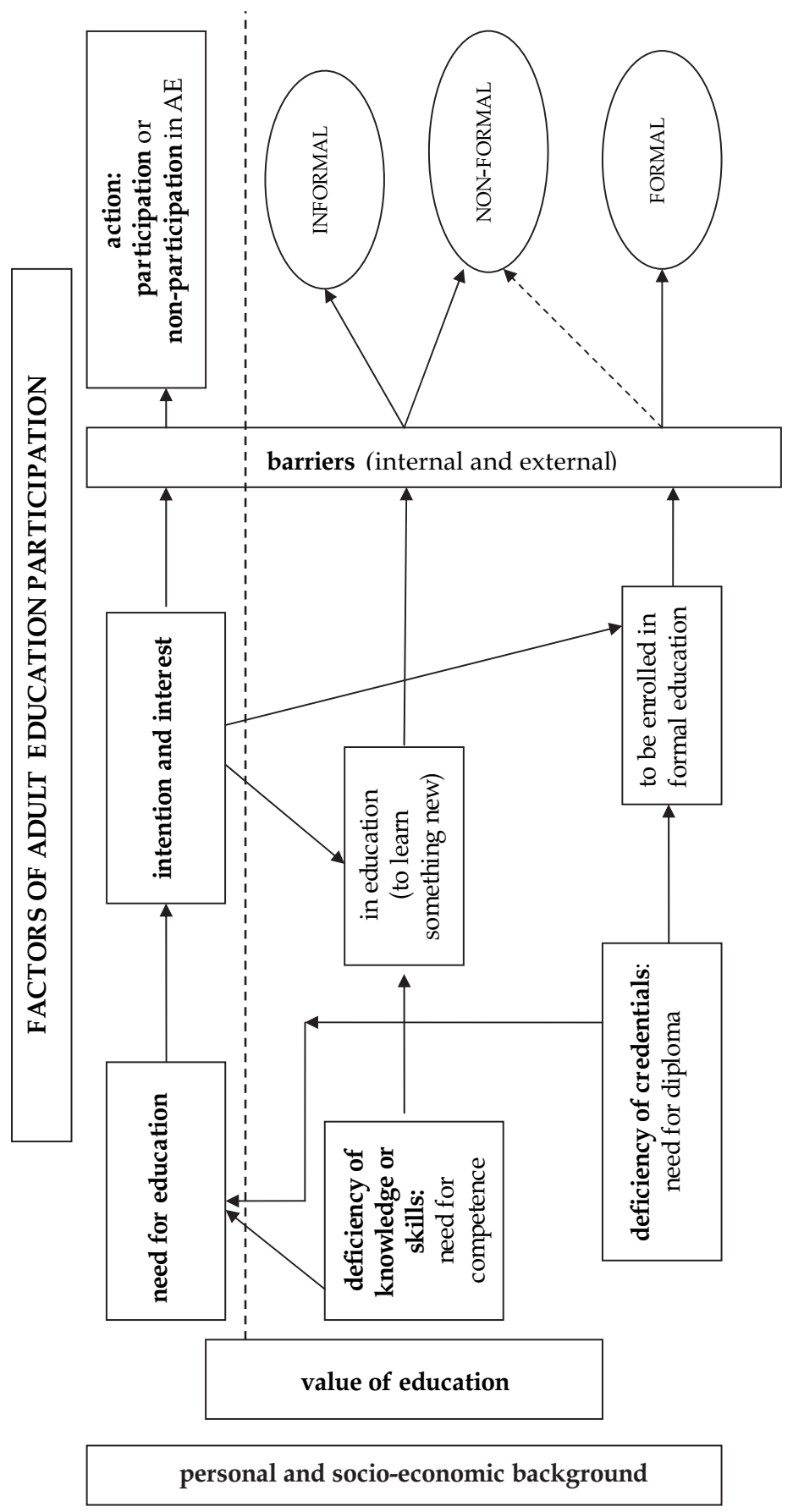


a range of factors contained in their personal and socio-economic background and on the value attribute to them. These elements then serve as motives for action. People also weigh the implications of their actions, which is another important factor in their decision-making process. Moreover, people's objectives in taking certain actions are crucial determinants of the actions themselves. Therefore, to understand why people do not continue their formal education or do not participate in informal adult-education courses, in the survey we asked people about their reasons for their decision and about the perceived barriers and constraints.

\section{Results}

Before we present our results, let us have a look at the general European picture of lifelong learning. The data come from the 'Ad Hoc Module on Lifelong Learning', a survey carried out by Eurostat in 2003 on representative samples of the population aged 25-64. As Figure 2 shows, 42\% of the EU population aged 25-64 had participated in some form of formal, non-formal or informal education, training, or learning activity over the twelve months prior to the survey and $52 \%$ had not. The

Figure 2. Participation rate in any kind of learning in the EU 25 in 2003 (population of 25-64 year-olds)

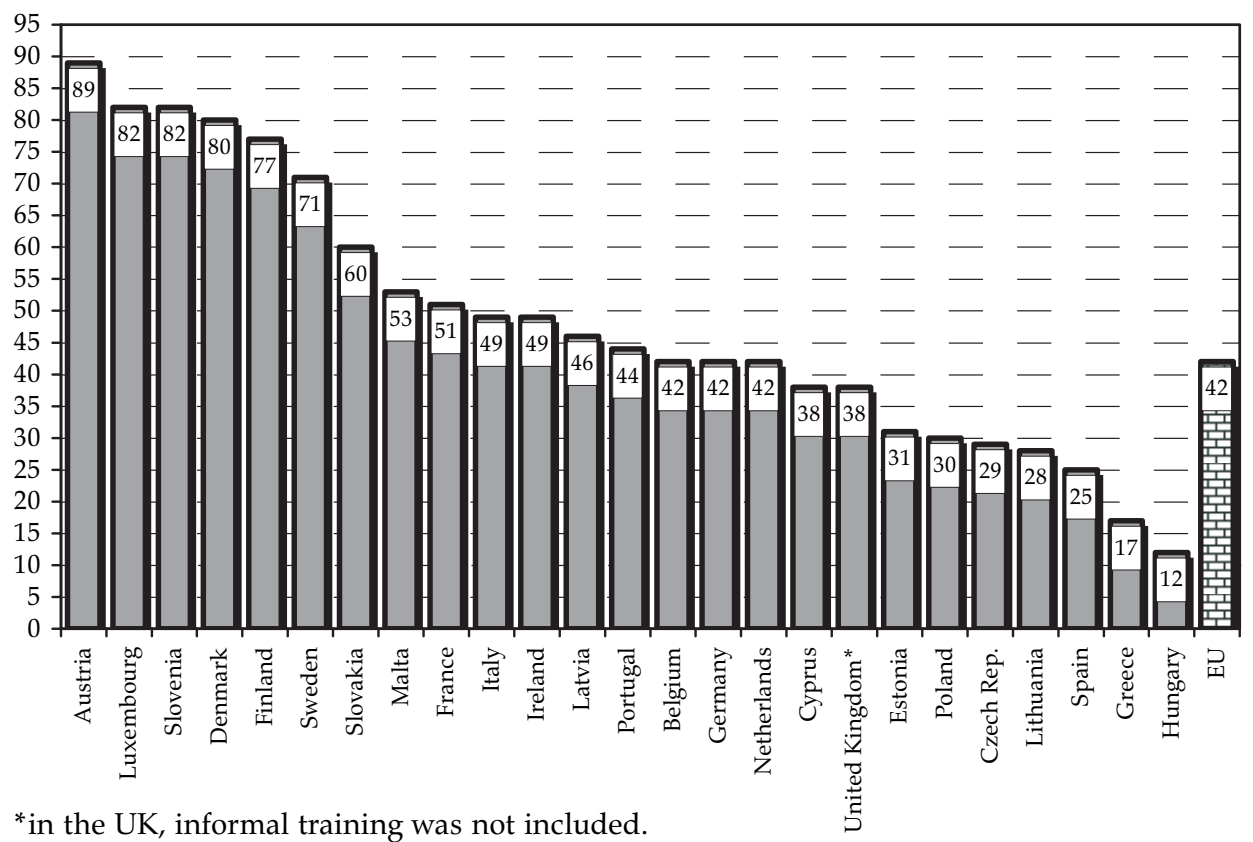

Source: Eurostat [2005: 2, Table 1]. 
Czech Republic belongs to the group of six countries with the lowest participation rate, at less than one-third of the population.

To get a more detailed picture and find out what are the reasons for such a low participation rate, we will now look at our special Czech survey on adult education.

\section{Adult participation in formal education}

The first part of our analysis of adult education deals with the participation of adults in formal education. Here we are interested in learning about the educational trajectories of our respondents: whether their participation in adult education was part of an uninterrupted personal educational history, or whether it was rather a return to study again at an educational institution (high school or university) after a pause. To ensure clear results, student respondents who were at the time of the interview enrolled in their first or initial cycle of education were excluded from the analysis conducted for the purpose of this article.

The results show that only a very small proportion of adults go back to formal studies after a break - less than $9 \%$ of the respondents in our survey. We can use this fact to infer that the acquisition of formal education in the Czech Republic tends to follow the traditional model: people complete their compulsory schooling, and those who want to continue their education do so immediately. Most conclude studying as soon as they reach 'their educational level', and only a small minority returns to school after some time. Only 3\% of respondents with a low level of education (i.e. compulsory nine-year schooling) recommenced their studies after a break, along with $3 \%$ of respondents with a vocational certificate, $13 \%$ of respondents with secondary school, and $29 \%$ of respondents with a university diploma.

This model was observed not only among older respondents but also among the youngest generation, i.e. those aged 20-35 (born between 1970 and 1985). This finding indicates that the traditional life cycle is still prevalent in the Czech Republic: people finish their education first and only then enter the labour market (and embark on their adult lives). This is not good news for modern society, in which lifelong education and a flexible life cycle should be primary [see, e.g., Muffels 1998].

As mentioned above, only $9 \%$ of the sample population decided to go back to school after a pause. The reasons for doing so included the desire to study higher vocational education (12\%), to obtain a secondary-school diploma (39\%), or to obtain a university degree (30\%). The primary motivations people had for increasing their level of education were work-related: a desire to improve the job opportunities available to them (53\%), or a requirement stipulated by their employer $(17 \%)$. For $23 \%$ of respondents personal development was the reason for enrolling in school again after a break in studying.

Knowing what motivated our respondents to take steps to increase their level of education should also tell us why a major part of them did not continue their education at the secondary or tertiary level. Our 2005 data can be compared with da- 
Table 1. Reasons for the discontinuation of formal education (\%)

\begin{tabular}{lcc}
\hline & Adult education & IALS \\
& 2005 & 1997 \\
\hline I had reached a sufficient level of education & 27.5 & 13.4 \\
I had to get a job & 16.3 & 24.5 \\
I wanted to get a job & 22.9 & 20.6 \\
Family reasons & 7.4 & 16.6 \\
I didn't like school & 7.0 & 8.8 \\
I was not successful at school & 6.5 & 3.0 \\
Health reasons & 1.1 & 1.8 \\
I didn't gain admission to the school of my choice & 5.4 & 4.3 \\
I went to serve in the army & 2.9 & 0.6 \\
Other reasons & 3.2 & 6.4 \\
\hline
\end{tabular}

Note: People currently studying were excluded from the analysis.

Source: Adult Education in the Czech Republic 2005 dataset.

ta from the IALS research from 1997, which asked a similar question. The results are shown in Table 1.

In 2005, the most frequently cited reason Czech adults had for not continuing their formal education was that they had already reached their desired level of education (27\% of respondents), while $23 \%$ of respondents indicated that they had not continued to study because they wanted to get a job and $16 \%$ because they had to get a job. This means that getting a job was the reason for discontinuing their studies for $39 \%$ of respondents, i.e. over one-third. Another $7 \%$ of respondents gave up their education because they did not like school and $6 \%$ because they were not successful at school, which means that the school environment was de-motivating and was the reason for discontinuing study among $13 \%$ of respondents. Another $7 \%$ of respondents cite family reasons and 5\% say they were unsuccessful in their attempt to enrol in the school of their choice. The remainder of respondents reported other reasons.

A significantly different situation existed in 1997, i.e. eight years before our research. Significantly more people claimed they had to find a job (25\%), while those claiming they had achieved the desired level of education (13\%) were fewer in number. Family reasons were another rather frequent barrier to continued study.

If the interval of eight years between the two surveys allows us to make any conclusions, then the contemporary situation seems to suggest that people now tend to make decisions about their educational careers less under the pressure of external circumstances ('I had to get a job', 'I had to discontinue my studies for family reasons') and to a greater degree are responsible for their own decisions ('I had reached the level of education I intended to reach').

In the context of a learning society, the crucial question is: do Czech adults plan to study in the future? Our results suggest that Czech people are not too eager 
to return to school in the near future in order to get a formal certificate of education. This attitude was expressed by $88 \%$ of respondents. People planning to study $-12 \%$ of the sample - tended to be young respondents aged 20-35 (the statistical association for ordinal data is 0.33 ) and respondents who had reached the level of higher education (association 0.15). Apart from young and relatively well-educated people, that figure of potential students included people who do not regard their occupational knowledge and skills as sufficient ${ }^{5}$ and people who believe that improving their qualifications may make a difference for them in their jobs. ${ }^{6}$

We tested a hypothesis that the plan to study would be motivated by a person's sense of a risk of losing their current job or, among the self-employed, a risk of failure. However, that proved incorrect. First, we discovered that the fear of losing one's job or of failure among the self-employed are not common motivations among Czech respondents: $48 \%$ of respondents believe the probability of job loss or professional failure is low, $44 \%$ believe it a moderate risk, and $8 \%$ believe the risk is high. Second, whether big or small, the sense of risk does not motivate people to study. The plan to study was also not dependent on gender, age, or level of education - no such associations were observed. The absence of any connection with age is interesting. Even people over the age of 50, who are at a considerable risk of unemployment in the Czech Republic, did not rate their risk as high significantly more often than younger respondents.

To sum up this section, formal education, i.e. studies leading to the acquisition of a diploma or a certified qualification, as a means of increasing or maintaining one's education, does not attract many Czech adults. This is despite the fact that most universities and higher vocational schools have recently been returning to a system of extramural studies, which had come close to being abolished in the Czech Republic in the early 1990s, and that kind of educational offer has been expanding significantly year by year.

Considering that the Czech adult population shows little interest in formal education, theoretically room should be left for non-formal education. Let us therefore look at whether this is the educational mode that the Czech adult population prefers: a mode that in a way seems easier, is undoubtedly faster, is very current, and is often down-to-earth and easy to make use of in practice. The results that have become available so far suggest that the pressure of the knowledge society has not yet affected knowledge and skills development in any significant way, just as it has not affected people's behaviour in the labour market.

\footnotetext{
5 To illustrate the point: as many as $44 \%$ of all respondents regarded their level of occupational knowledge and skills quite sufficient in the current situation, and $50 \%$ as rather sufficient, while a mere $6 \%$ regarded their knowledge and skills as inadequate.

${ }^{6}$ Again, for the sake of illustration, we can note respondents' opinions on the potential change in their job situation if they were to increase their education: $13 \%$ believe it would definitely change and $18 \%$ think it would rather change, which equals $31 \%$ in total; $69 \%$ of respondents thought an increase in their educational attainment would for them signify no change in their jobs or occupations.
} 


\section{Czech adults in non-formal education}

We measured participation in non-formal adult education using questions about the learning activities in which respondents may have participated during the twelvemonth period prior to the interview. We distinguished seven types of non-formal learning activities: 1) job-related courses, 2) foreign language courses, 3) computer courses, 4) personal development courses (e.g. courses in psychology, mental development, and so on), 5) courses on parenting or partner relationships, 6) courses on leisure-time activities (e.g. on how to do certain sports or how to paint, etc.), 7) courses on civic activities (e.g. to understand matters of local administration, to learn about environmental activities, and so on). We also asked about whether the respondents intended to participate in these learning activities in the near future.

The data we obtained (in the survey) show that in the Czech Republic 34\% of people attended some kind of course in non-formal education during the twelve months prior to the survey, while $66 \%$ of respondents did not take part in any kind of non-formal education. Of those that participated in some form of non-formal education, $18 \%$ attended just one course, $10 \%$ attended two, and $6 \%$ attended three or more. In order to judge whether these figures are high or low, we can compare them with results obtained in similarly oriented research projects undertaken over the past ten years in the Czech Republic, Finland, Canada, and the United States. The figures are presented in Table 2.

We can see that the figures differ considerably - not only in an international comparison, but also between the individual Czech studies. We believe that the differences can be ascribed primarily to different measurement methods. Since the questions were not formulated identically, the methods of measurement were different - the figures are more a reflection of the differences between the surveys than actual differences in participation rates. Let us therefore review the individual methods of enquiry.

Table 2. Participation in courses of non-formal adult education in the Czech Republic, Finland, Canada, and the USA

\begin{tabular}{|c|c|c|c|c|c|}
\hline & Czech Republic & Finland & Canada & & USA \\
\hline & $19972003 * 2005$ & $199520002003^{*}$ & 19931997 & 1995 & 19992001 \\
\hline & $13 \%$ & $48 \% \quad 54 \% \quad 41 \%$ & $30 \% \quad 28 \%$ & $40 \%$ & $45 \%$ \\
\hline $\begin{array}{l}\text { Population } \\
\text { surveyed: }\end{array}$ & $20-65 \quad 20-64 \quad 20-65$ & $18-64$ & $\begin{array}{l}17+\text {, regular } \\
\text { students excl. }\end{array}$ & & $16^{+}$ \\
\hline
\end{tabular}

Note: The data from the Czech Republic were collected as part of IALS in 1997 by the Czech Statistical Office within the Eurostat 'Ad Hoc Module on Lifelong Learning' in 2003 and in our survey 'Adult Education in the CR' in 2005.

* Eurostat Ad Hoc Module Survey

Source: Statistics Finland [2000]; Statistics Canada [2001]; Kim et al. [2001]. 
Czech Republic:

1997 (IALS): Have you attended a course or training in the past twelve months? For instance, a course to increase your qualifications, to change your qualifications, a language course, a distance learning course, a course to increase your skills, or any other types of learning? (Yes or no question)

2003 (Eurostat Ad hoc Module): Have you attended (or completed) a course of non-formal education in the past twelve months? (Yes, 1 course; Yes, 2 courses; Yes, 3 courses; Yes, 3 courses or more; No)

2005 (Adult Education): Have you attended in the past twelve months: work-related courses, foreign language courses, computer courses, personal development courses (e.g. courses in psychology, mental development, and so on), courses on parenting or partner relationships, courses on leisure-time activities (e.g. to learn how to perform some sport or how to paint, etc.), courses on civic activities (e.g. to learn about matters of local administration or environmental activities, and so on). (Yes or no question)

Finland:

The same wording both years: Have you participated in training at the following general education institutions in the past twelve months? (Followed by a detailed list of 19 possible options of adult education) [see Statistics Finland 2000: 7-9].

Canada:

At any time during 1997 did you receive any training, or education, including courses, private lessons, correspondence courses (written or electronic), workshops, apprenticeship training, arts, crafts, recreation courses, or any other training or education? (Respondents were also asked to make a distinction between participation for job or career-related purposes and participation motivated by personal interest.) [Statistics Canada 2001]

United States:

Adults were asked about participation in seven types of formal adult education activities during the twelve months prior to the interview: English as a Second Language (ESL), basic skills education, part-time post-secondary degree or diploma programmes, apprenticeship programmes, work-related courses, and personal interest courses. However, if an adult was pursuing a master's degree on a part-time basis he/she was included in the calculation of the overall participation rate, because their part-time participation in a post-secondary programme is considered adult education. [Kim et al. 2004]

Our results seem to confirm the suspicion that occasional scepticism about the reliability of different international and Czech comparisons is well-founded. What strikes the eye particularly is the difference between the Czech data from 2003 (taken from the 'Ad Hoc Module') and 2005 (Adult Education Survey). Moreover, a similar difference occurred in the case of Finland. The fact that the Eurostat 'Ad Hoc Module' arrived at such a low figure is, in our opinion, due to the brevity of the question it posed, as a result of which respondents were not clearly aware of what kinds of educational activities non-formal education includes. The validity of the figure can therefore be challenged. However, we do regard the results of the IALS research of 1997 and our research of 2005 as valid, and we believe that with some license they are internationally comparable.

In this context, the participation of one-third of Czech adults in at least one course of non-formal education over the past twelve months is a fairly good result. 
Table 3. Overall participation in non-formal education in the past twelve months and the intention to participate in such activities in the next twelve months, by gender, education level, age, occupation, job status, and importance of education for success in life, CR, 2005 (\%)

\begin{tabular}{|c|c|c|}
\hline & $\begin{array}{c}\text { Participation } \\
\text { in AE } \\
\end{array}$ & $\begin{array}{l}\text { Intention } \\
\text { to participate }\end{array}$ \\
\hline \multicolumn{3}{|l|}{ Gender } \\
\hline Male & 34 & 34 \\
\hline Female & 34 & 37 \\
\hline \multicolumn{3}{|l|}{ Level of education } \\
\hline Below secondary & 12 & 12 \\
\hline Vocational & 23 & 29 \\
\hline Secondary completed & 49 & 49 \\
\hline Tertiary & 68 & 66 \\
\hline \multicolumn{3}{|l|}{ Age groups } \\
\hline $20-29$ & 42 & 47 \\
\hline $30-39$ & 43 & 48 \\
\hline $40-49$ & 39 & 39 \\
\hline $50-59$ & 32 & 32 \\
\hline $60-65$ & 12 & 13 \\
\hline \multicolumn{3}{|l|}{ Occupation } \\
\hline Employee & 47 & 45 \\
\hline Self-employed & 37 & 34 \\
\hline Unemployed & 19 & 31 \\
\hline Retired & 7 & 12 \\
\hline $\begin{array}{l}\text { Parental leave } \\
\text { Job status }\end{array}$ & 25 & 31 \\
\hline Blue-collar, unqualified & 27 & 29 \\
\hline Blue-collar, qualified & 31 & 29 \\
\hline Clerical, sales, service & 53 & 57 \\
\hline Professional, managerial & 77 & 64 \\
\hline $\begin{array}{l}\text { Self-employed } \\
\text { Importance of education }\end{array}$ & 38 & 34 \\
\hline Low importance & 31 & 33 \\
\hline High importance & 43 & 46 \\
\hline
\end{tabular}

Source: Sources are the same as in Table 2. 
Moreover, there has been an upward trend since 1997, which corresponds with the aims of a knowledge society. Czech adults participate in non-formal education less than, for example, Finns or Americans do, but more than Canadians (taking into account that measurement methods were different and the age structure of the sample populations was different). ${ }^{7}$ It seems, therefore, that non-formal education does provide a counterbalance to the prevailing lack of interest in formal education among Czech adults, which is certainly a positive observation.

Let us now explore the characteristics of participants in non-formal education in greater detail. They are presented in Table 3, and there we have also included data on respondents' actual participation over the past twelve months and data on their intention to participate in courses and activities of non-formal education in the near future, i.e. in the next twelve months.

We can conclude that there is no difference between the participation of men and women, whereas there is a difference between groups with different levels of education (ordinal association tau-c $=0.39$ ). Courses were attended by $68 \%$ of university graduates, $49 \%$ of secondary-school graduates, $23 \%$ of people with vocational certificates, and $12 \%$ of people with a low level of education. Eurostat found the same trend. In the EU-25, the proportion of people with high levels of education that participated in non-formal education was twice as high as it was for those with mid-level education and four times as high as for people with low education [Eurostat 2005: 13, Table 2]. The conclusion Sargant et al. [1997] reached from the results of an adult learning survey in the UK were the same: completed education is the strongest predictor of participation in adult learning.

There were also some differences connected with age (tau-c $=-0.22$ ), the participation of younger people being higher. The rate of participation was $43 \%$ among people aged 20-29 and 30-39, while older people attended courses of non-formal education less often (32\% among people aged 50-59). The highest participation rate was among employees (47\%) and self-employed people, and people on parental leave also had a strong attendance rate $(25 \%)$, while unemployed people attended courses only rarely. As far as different types of employment are concerned, non-formal education was most often pursued by managers and professionals $(77 \%)$, followed by office staff of all kinds (53\%), while unqualified blue-collar workers attended such courses least $(27 \%)$. The relative importance ascribed to education with regard to success in life plays a role, too: People who regard it as very important participate in education more often than those who do not regard education as a tool for achieving success in life.

\footnotetext{
7 The Canadian interpretation of the result is inspiring: "First, with $28 \%$ of Canadians participating in 1997, it is clear that adult education is a major sector within education deserving close policy attention. Second, this figure, although impressive, suggests that Canada still has some way to go before it becomes a more inclusive learning society. Third, the results generally support the idea that Canadians invest in education as a means of staying competitive on the job market." [Statistics Canada 2001: 13]
} 
Table 4. Adjusted odds ratios showing the likelihood of adult education participation during the past twelve months and of the intention to take part in adult education and training in the next twelve months, by selected characteristics, CR, 2005

\begin{tabular}{|c|c|c|}
\hline & $\begin{array}{c}\text { Participation } \\
\text { (adjusted odds ratio) }\end{array}$ & $\begin{array}{c}\text { Intention } \\
\text { (adjusted odds ratio) }\end{array}$ \\
\hline \multicolumn{3}{|l|}{ Gender } \\
\hline Male & 0.00 (ref.) & 0.00 (ref.) \\
\hline Female & 1.20 n.s. & 1.13 n.s. \\
\hline \multicolumn{3}{|l|}{ Education } \\
\hline Lower secondary & 0.00 (ref.) & 0.00 (ref.) \\
\hline Vocational & 1.50 n.s. & 1.14 n.s. \\
\hline Secondary completed & $3.47 * *$ & 0.80 n.s. \\
\hline Tertiary & $6.27 * *$ & 1.42 n.s. \\
\hline \multicolumn{3}{|l|}{ Age groups } \\
\hline 20-29 & 0.00 (ref.) & 0.00 (ref.) \\
\hline $30-39$ & $1.68 *$ & 1.15 n.s. \\
\hline $40-49$ & 1.10 n.s. & 0.59 n.s. \\
\hline $50-59$ & 1.05 n.s. & 0.73 n.s. \\
\hline $60-65$ & 0.87 n.s. & $0.14 * *$ \\
\hline \multicolumn{3}{|l|}{ Job status } \\
\hline Blue-collar, unqualified & 0.00 (ref.) & 0.00 (ref.) \\
\hline Blue-collar, qualified & 1.16 n.s. & 0.83 n.s. \\
\hline Clerical, sales, service & 1.53 n.s. & $2.48^{* *}$ \\
\hline Professional, managerial & $2.78 * *$ & 1.44 n.s. \\
\hline Self-employed & 1.02 n.s. & 1.08 n.s. \\
\hline \multicolumn{3}{|l|}{ Importance of education } \\
\hline Low & 0.00 (ref.) & 0.00 (ref.) \\
\hline High & 1.09 n.s. & 1.33 n.s. \\
\hline \multicolumn{3}{|c|}{ Participation in the past 12 months } \\
\hline No & $x$ & 0.00 (ref.) \\
\hline Yes & $x$ & $18.29^{* *}$ \\
\hline Constant & $0.19 * *$ & $0.15^{* *}$ \\
\hline
\end{tabular}

Note: n.s. $=$ not significant; ${ }^{*} \mathrm{p}<0.05 ;{ }^{* *} \mathrm{p}<0.01$

Model characteristics for participation:

Chi-square is statistically significant (the data-based model explains the dependent variable better than the constant-based model), Nagelkerke R square $=0.20$, the Hosmer and Lemeshow test is not significant (meaning that model data and real data do not differ) and the share of correctly classified cases was $67 \%$.

Model characteristics for intention:

Chi-square is statistically significant (model with data explains dependent variable better than the model with constant only), Nagelkerke R square $=0.50$, the Hosmer and Lemeshow test is not significant $(\mathrm{p}=0,08)$ and the share of correctly classified cases was $81 \%$. Source: Sources are the same as in Table 2. 
When we look at the intention to participate in education in the near future, we find the same trends as with past participation. But there are two different figures: more unemployed plan to participate in courses of non-formal education than actually do in reality ( $31 \%$ vs. $19 \%$ ). By contrast, fewer managers plan to participate in these courses in the future than those who have already participated in non-formal education. There is a logic to both results. Overall, the total number of respondents planning to attend courses of non-formal education was $36 \%$, which is just slightly more (by $2 \%$ ) than the real participation rate.

One very significant, if rather paradoxical, finding is that people who felt that the level of their knowledge and skills was sufficient for their occupation attended courses of non-formal education more often (46\%) than those who felt their skills insufficient (33\%). A comparison of people who feel at risk of job loss or failure in selfemployment and people who attend adult-education courses produces equally paradoxical results. Those who hardly feel threatened by this kind of risk participate in education just as often (50\%) as those who this sense of threat is medium (41\%) or strong (47\%).

Since the individual characteristics of respondents may be interrelated (e.g. the level of education certainly relates to job status), we should look at their net effect on participation in non-formal education. Since the dependent variable is binary and the independent variables are categorised, the situation is ideally suited to logistic regression. The results are presented in Table 4 .

As far as past participation is concerned, the net effect of individual variables has changed, compared to bivariate relations. Education was revealed to have a significant effect: the odds of participation of people with tertiary education are 6.3 times higher than those of people with below secondary education. However, the rather huge differences in the odds ratio with respect to job status, as shown in Table 3, disappeared when the effect of other variables was statistically controlled for. There is a significant effect in one job status category only, namely, professionals and managers, among whom there is a 2.8 times higher chance that they participated in adult education activities in the past twelve months than unqualified bluecollar workers. The adjusted effect of age and of the opinion on the importance of education for one's success in life are almost zero. This model shows that it is actually only people with higher levels of education, professionals, and people in managerial positions whose odds of having participated in adult education activities in the past twelve months are statistically significant.

There is one obvious reason for the difference in the results of the analysis of intentions to participate in the future: the addition of another independent variable - participation in the past twelve months. If we wish to explain the intention to participate in courses of non-formal education in the near future, this variable turns out to be key: the chance that respondents would participate in non-formal courses within the next twelve months, expressed by those who attended such courses within past twelve months, was eighteen times higher than for those who had attended no such courses. The effect of other variables is not significant. Only clerks and 
Table 5. A typology of respondents based on participation in adult education over the past twelve months and the intention to attend courses of non-formal education in the following twelve months

\begin{tabular}{lccc}
\hline & $\begin{array}{c}\text { No intention } \\
\text { of participation }\end{array}$ & $\begin{array}{c}\text { Participation } \\
\text { intended }\end{array}$ & Total \\
\hline No past participation & $56 \%$ & $10 \%$ & $\mathbf{6 6 \%}$ \\
Past participation & $8 \%$ & $26 \%$ & $\mathbf{3 4 \%}$ \\
Total & $\mathbf{6 4 \%}$ & $\mathbf{3 6 \%}$ & $\mathbf{1 0 0 \%}$ \\
\hline
\end{tabular}

Source: Sources are the same as in Table 2.

sales people plan to educate themselves in non-formal courses and training more often than unqualified blue-collar workers (i.e. the reference category) - their odds are statistically significant. The significant effect of education disappeared for intentions to participate and thus plays no role. The effect of age is, quite logically, opposite to what it was in the case of past participation; only the oldest portion of the population is significant. People in the oldest age group (60-65) are $86 \%$ less likely ${ }^{8}$ to plan participation than the youngest age group (20-29).

The key role of past participation in non-formal education for intended participation in the immediate future is evident even in a simple typology of respondents based on the dichotomy between past and future participation, as shown in Table 5 .

The table confirms that the proportion of people who had participated in this form of education (34\%) and who intend to participate in it (36\%) is almost equal. Moreover, the association between these two characteristics is high (Kendall's tau-b $=0.61$; $85 \%$ of respondents who had not attended such courses within the past twelve months had no intention of attending them in the next twelve months either, compared to $15 \%$ of respondents who intended to do so. Among those who attended such courses, $77 \%$ of respondents planned to go on with this form of education while $12 \%$ did not. Past participation clearly has a strong effect on intended participation, and a lack of participation in the past predicts a lack of intended participation.

\section{What prevents people from participating in non-formal educational activities?}

We have seen above that at present approximately one-third of adults participate in non-formal education in the Czech Republic, and approximately one-third of adults plan to participate in these activities in the near future. This raises the question of

$8(1-0,0.14)^{*} 100=86 \%$. 
Table 6. Barriers to participation in non-formal education (answers 'Agree' and 'somewhat agree' added together, just as 'somewhat disagree' and 'disagree')

\begin{tabular}{lcc}
\hline Barrier & $\begin{array}{c}\text { Agree } \\
(\%)\end{array}$ & $\begin{array}{c}\text { Disagree } \\
(\%)\end{array}$ \\
\hline I'm too busy at work & 55 & 45 \\
I don't have enough financial resources at the moment & 49 & 51 \\
For me there is no point in participating in courses or training & 39 & 61 \\
I have many hobbies and therefore no time for further & 37 & 64 \\
educational activities & 32 & 68 \\
I have no time for further education because I have to take & & 72 \\
care of my children/family & 28 & 72 \\
I'm afraid it would be too difficult & 28 & 73 \\
There isn't enough information available on suitable courses & 27 & 73 \\
I don't think I'm educated enough to participate in further & & 76 \\
education & 27 & 92 \\
There aren't enough courses. & 24 & 8 \\
The quality of the courses is relatively low & & \\
I cannot participate for health reasons & &
\end{tabular}

Source: Sources are the same as in Table 2.

why the proportion is so low. As Cross [1981] has shown, the perceived barriers to learning can be classified into three groups: a) situational barriers arising from one's situation at a given time (e.g. lack of money, lack of time, lack of transport to the study venue); b) institutional barriers (e.g. inconvenient schedules, lack of appropriate programmes); c) dispositional barriers related to attitudes and self-perceptions about oneself as a learner (e.g. feeling 'too old' to learn, a lack of confidence, tired of school). Various research reports suggest that the strength of such factors varies significantly between countries [Smith 2005].

The barriers that Czech respondents perceive as preventing them from participating in educational activities are shown in Table 6. (Retired respondents were excluded from this analysis.) Respondents most often claimed occupational overload (being too busy at work) - 55\%. This barrier was cited mainly by self-employed respondents $(75 \%)$ and blue-collar workers (66\%). Financial reasons were the second most frequent barrier mentioned (49\% of respondents). ${ }^{9}$ Here, a statistically significant and moderate association with the level of respondents' income was observed: the lower the income, the more frequently this item was cited (Kendall's tau-c = 0.36). The positive message in Table 6 is that barriers like the quality of courses, $a$

\footnotetext{
${ }_{9}$ For instance, the cost of programmes was a highly significant reason in the UK. On the other hand, in the USA it is far less important [Smith 2005].
} 
Table 7. Factor analysis loadings of barriers to adult education. Rotated component matrix

\begin{tabular}{|c|c|c|c|c|}
\hline \multicolumn{5}{|l|}{ Components } \\
\hline & 1 & 2 & 3 & 4 \\
\hline $\begin{array}{l}\text { I don't think I'm educated enough to participate } \\
\text { in further education }\end{array}$ & 0,864 & & & \\
\hline I'm afraid it would be too hard & 0,850 & & & \\
\hline $\begin{array}{l}\text { I don't have enough financial resources } \\
\text { at the moment }\end{array}$ & 0,505 & & & \\
\hline $\begin{array}{l}\text { There is no point for me participating in courses } \\
\text { or training }\end{array}$ & 0,488 & & 0,434 & \\
\hline There aren't enough courses. & & 0,869 & & \\
\hline $\begin{array}{l}\text { There isn't enough information available } \\
\text { on suitable courses }\end{array}$ & & 0,836 & & \\
\hline The quality of the courses is relatively low & & 0,614 & & \\
\hline I'm too busy at work & & & 0,777 & \\
\hline $\begin{array}{l}\text { I have many hobbies and therefore no time } \\
\text { for further education }\end{array}$ & & & 0,725 & \\
\hline $\begin{array}{l}\text { I have no time for further education because I have } \\
\text { to take care of my children/family }\end{array}$ & & & & ,730 \\
\hline I cannot participate for health reasons & & & & 661 \\
\hline
\end{tabular}

Note: Extraction method - principal component analysis, rotation method: Varimax with Kaiser Normalisation.

Kaiser-Meyer-Olkin Measure of Sampling Adequacy = 0,71, Sig. $=0,001 ; 64 \%$ of explained variance. Loadings smaller than 0.39 were omitted from the table.

Source: Sources are the same as in Table 2.

lack of information, or a lack of self-confidence was mentioned by only about onequarter of the respondents and thus are not regarded as a significant barrier to nonformal adult education.

With regard to Cross's conceptualisation of barriers, we did not find a similar structure in our data. A factor analysis of our set of barriers produced the grouping in Table 7. However, institutional barriers (not enough courses, not enough information, and the quality of courses) do form one component. On the other hand, situational barriers and dispositional barriers are rather mixed. Moreover, we found a fourth barrier as a factor - too busy with one's children/ family, and for health reasons. In Cross's perspective they would rank among situational barriers, but here they formed a specific factor.

Clearly the reasons respondents have for indicating these statements as important or not may be considerably subjective. In some case they may even distort reality. For instance, to say that the barrier to participating in adult education is a lack of adequate financial resources may sound, from the respondent's perspective and in an interview situation, like a very legitimate reason that in no way damages 
his/her reputation. Nevertheless, these expressed reasons are an important source of data, as they communicate a message about how people justify in their own eyes the fact that they are not interested in further education. The reasons reveal the way in which respondents construct their (non)-educational reality.

\section{Conclusion}

In the introduction of this article we noted the basic characteristics of lifelong learning and posed three fundamental questions to allow us to describe some attributes of adult education in the Czech Republic. Let us now sum up what our data tell us about lifelong learning and adult education.

Has education begun to be perceived by the Czech population as a lifelong activity or is it still regarded as something engaged in during a certain stage in life, specifically, the period of compulsory school attendance? Our results show that the classic life path clearly prevails among the adult population and including younger age groups. The student stage precedes the occupational and family stages. Only a very small proportion (9\%) of the Czech population resumes formal study at a secondary school or university after that stage is terminated; among those who do, most do so to attend university. The primary motivations for returning to formal study are external, particularly occupational, while the desire for personal development is cited less often as a reason. Also, those who neither study nor intend to do so in the near future - and they form the vast majority of the population (88\%) tend to remain unmoved by concerns such as losing one's job, failing to support oneself through self-employment, or other occupational issues. The small group of people who plan to study in the near future are typically young, with a relatively high level of education, and with a desire to improve their skills. The figures for nonformal educational activities, in which one-third of the Czech adult population is involved, are more favourable.

Does lifelong learning comprise more than just formal education organised by educational institutions and include all forms and types of learning, regardless of the institution or environment, in settings like the workplace, the home, or the municipality? Do all learning opportunities form an entirety allowing for heterogeneous and frequent switches between education and work and providing an opportunity to obtain the same qualifications and competencies in different ways throughout one's life? Our results suggest that a relatively large part of the Czech population participate in non-formal education, which could provide a basis for a future system of qualifications and skills acquisition. One-third of the population claim to have participated in one kind of non-formal activity during the past year and one-third of the population are planning to participate in such activities within the next year. It is mainly younger and better-educated people and people motivated primarily by occupational reasons who participate in non-formal education. In this regard interconnection between different learning environments - the workplace, the home, and the municipality - has yet to be established. Therefore, we 
reached the conclusion that a great majority of courses attended by adults are related to their jobs, or computers, or foreign languages. (These conclusions derive from analyses that were not included in this paper owing to length constrictions.) All other areas (leisure time, family, public life, etc.) were almost absent among the motivations for their educational activities.

Does learning provide opportunities for everybody regardless of age, interests, talent, or social status? The data do not tell us whether learning opportunities are really available to everybody and to what extent, but we can infer this information from the characteristics of the people who participate in both formal and non-formal education, which suggest that the most likely participants have a good level of education, are young and have already participated in some form of lifelong learning. This is an alarming finding, as it points to a situation where those who are most in need of further education do not participate in it. While it is positive to learn that gender is not a barrier to education, it is disturbing to find that fear of unemployment or of failing to support oneself through self-employment do not play any role. We were also able to identify some subjective barriers. These can be alleged external barriers (lack of finance or lack of time due to an excessive workload or taking care of one's family) or internal barriers, such as doubts about the meaningfulness or quality of the courses or self-doubt ('I'm not educated enough', 'It would be too difficult').

We opened the article with a note about the dynamic nature of knowledge societies and, by association, the dynamic nature of changes in the area of education in terms of both the content and the structure of education systems. This has resulted in changes initiated from above - by competent decision-making institutions - and, most importantly, from below - by individuals, groups, companies, educational institutions, and other institutions, which will have to begin to regard lifelong learning (and adult education) an essential part of life. For this reason we believe that the findings presented here will only be valid for a limited time. Optimistically we may expect similar research to yield considerably more favourable results within as soon as several years: in this dynamic and competitive world there simply is no other option.

LADISLAV RABUŠIC is a professor in the Department of Sociology, Faculty of Social Studies, Masaryk University, Brno. His research is focuses on the sociological aspects of population trends (e.g. below replacement fertility, ageing, migration), the sociological aspects of social problems (poverty, unemployment), and adult education and lifelong learning. He has been the Czech co-ordinator of the European Values Study project, and is the author of two monographs: 'Ageing Czech Society' (1995), and 'Where Have All the Children Gone - Fertility in Sociological Perspective' (2001). He edited a book in Czech titled Czech Society and the Elderly (1997) and has also published a number of papers on population studies.

MiladA RABUŠICOVÁ is an associate professor in the Department of Educational Sciences, Faculty of Arts, Masaryk University, Brno. She is interested in comparative pedagogy, es- 
pecially comparative educational policy, and adult education in the system of lifelong learning, and she also focuses on sociology of education, especially on family-school relationships. She is the author of numerous papers and a textbook on sociology of education (1991), co-editor of the book entitled Management and Governance of Schools: Boards of Governors in an International Perspective (1996), and co-author of the book School and/versus/ Family (2004). Her most recent monograph is a book on problems of functional literacy based on an international survey of adult literacy, Literacy: An Old Topic in a New Perspective (2002).

\section{References}

Ajzen, Icek and Martin Fishbein. 1980. Understanding Attitudes and Predicting Social Behavior. Englewood Cliffs, NJ: Prentice Hall.

Becker, Gary S. 1993. 'Nobel Lecture: The Economic Way of Looking at Behavior.' Journal of Political Economy 101 (3): 385-409.

Boshier, R. 2001. 'Running to Win: The Contest Between Lifelong Learning and Education in Canada.' New Zealand Journal of Adult Learning 28 (2): 6-29. Available at: $<$ http://edst.educ.ubc.ca/faculty/boshier/article/learning.htm>.

Courtney, S. 1989. 'Defining Adult and Continuing Education.' Pp. 15-29 in Handbook of Adult and Continuing Education, edited by S.B. Merriam and P.M. Cunningham. San Francisco: Jossey-Bass.

Cross, K.P. 1981. Adults as Learners. Increasing Participation and Facilitating Learning. San Francisco: Jossey-Bass.

Dlouhodobý záměr vzdělávání a rozvoje výchovně vzdělávací soustavy České republiky. 2002. (The Long-term Plan for Education and the Development of the Education System in the Czech Republic) Prague: MŠMT.

Education at a Glance. OECD Indicators. 2005. Paris: OECD.

European Commission. 2000. A Memorandum on Lifelong Learning. Brussels: European Commission.

Eurostat. 2005. Lifelong Learning in Europe. Statistics in Focus. Population and Social Conditions. 8/2005, by E. Kailis and S. Pilos. Available at:

$<$ http://epp.eurostat.cec.eu.int/cache/ITY_OFFPUB/KS-NK-05-008/EN/KS-NK-05-008EN.PDF>.

Faure, E. 1972. Learning To Be. Paris: UNESCO.

Hiemstra, R. 2002. Lifelong Learning: An Exploration of Adult and Continuing Education Within a Setting of Lifelong Learning Needs. (Third Edition) Fayetteville, New York: HiTree Press.

Kim, K., M. Collins Hagedorn, J. Williamson and C. Chapman. 2004. Participation in Adult Education and Lifelong Learning: 2000-1 (NCES 2004-050). U.S. Department of Education, National Center for Education Statistics. Washington, DC: U.S. Government Printing Office.

Muffels, Ruud J. A. 1998. 'Stárnutí a flexibilizace. Hrozba nebo výzva pro sociální stát?' (Ageing and Flexibilisation. Caveats or Challenges for the Welfare State) Sociologický časopis 34 (3): 285-302.

Národní program rozvoje vzdělávání v České republice - Bilá kniha. 2001. (The National Programme of Educational Development in the Czech Republic - The White Book) Prague: MŠMT.

Sargant, N., J. Field, H. Francis, T. Schuller and A. Tuckett. 1997. The Learning Divide. 
A Study of Participation in Adult Learning in the United Kingdom. Leicester: National Institute of Continuing Adult Education.

Smith, M.K. 2005. 'Participation in Learning Projects and Programmes.' The Encyclopedia of Informal Education. Available at: <http://www.infed.org/biblio/b-partln.htm>

Statistics Canada. 2001. A Report on Adult Education and Training in Canada. Ottawa: Statistics Canada.

Statistics Finland. 2000. Adult Education Survey 2000. Introduction and Questionnaire. Statistics Finland.

Titmus, C.J. 1996. 'Adult Education: Concepts and Principles.' Pp. 9-17 in International Encyclopedia of Adult Education and Training, edited by A.C. Tuijnman. Second edition. Oxford, UK: Pergamon. 